\title{
The Obedience of Scrub Nurse Compliance in the Management of Surgical Instrument According to Procedure Operational Standard (POS) on Post- operative Sectio Cesarea in Lavalette Hospital Malang
}

\author{
Setyo Harsoyo ${ }^{1}$, Agussalim ${ }^{2}$ \\ ${ }^{1}$ Health Polytecnic of Malang, Indonesia, Nursing Program at Malang \\ ${ }^{2}$ Health Polytecnic of Jayapura, Indonesia, Nursing Program at Jayapura
}

\begin{abstract}
The management of the instrument are stages those are done scrub nurse in an effort to clean up and kills germs and bacteria from surgical tools used at the time of the operation. The purpose of this research is to know the compliance of scrub nurse in the management of the instrument according to Procedure Operational Standard (POS) on post-operative sectio cesarea. The design of this research is descriptive research survey with the subject observatif was 12 instrumentations operating room in Lavalette Hospital who conduct maintenance on post-operative surgical instrument of sectio cesarea. Data retrieval is performed on 17 May to 8 June 2016 by filling out the sheet of observations by observed the 12 respondents. In this study, the management of the instruments that have been undertaken by the respondents, comprising 12 stages limit and hold with an average value -81\%, average - with decontamination phase averages $94 \%$, the median average with lubrication $-54 \%$, the installation stage back and storage with an average value - $100 \%$ sterilization phase, with an average value of $99 \%$ - and the storage stage with an average value - 69\%. The recommendations in this study were expected throughout the respondents can sustain and increase discipline in performing surgical instrument management which is not yet done.
\end{abstract}

Keywords: Obedient, Surgery Instrument Management

\section{Background}

Sectio cesarea is the process of giving birth to the fetus, placenta and amniotic membrane through the abdominal wall by way of creating a wedge in the abdominal wall and uterus. Sectio cesarea can be implemented if the mother cannot give birth through a natural process. The operation was conducted with the goal of keeping the safety of mothers and babies can be handled properly. Therefore, many patients believe that giving birth by caesarean section would be better for the mother and baby from the process of giving birth normally (Williams, 2002). Sectio cesarea is carried out over a limited indication on a narrow pelvis and placenta previa. Increasing numbers of Genesis Sectio cesarea at this current time, among others, due to growing indications and makin her little risk and mortality in Sectio cesarea due to advances in engineering, operations and anaesthetic, as well as the potent of antibiotic (Mochtar, 2002).

According to the World Health Organization (WHO), the standard flat of Sectio Cesaria expression in the country is around 5\%-15\% per 1000 births in the world, government hospitals averaged $11 \%$, while in the private hospitals could be more than $30 \%$ (Gibbons, 2010). The numbers of Genesis Sectio Cesaria in Indonesia, according to national survey data in 2007 was 921,000 of $4,039,000$ of labor or about $22.8 \%$ of the entire labor inside the country (Rasjidi, 2009). According to the research of Sumana (2004) figures Sectio Cesaria in hospital Santa Elizabeth Terrain of 27.76 per cent and of $13.88 \%$ which is without medical indication Cesaria Sectio i.e. at the request of the mother's maternity itself (Sarmana, 2004).

From data capture which was done on December 3, was obtained by 2015 , that number of cases sectio cesarea from 1 January 2015 until 2 December 2015, totaling 151 cases sectio cesarea. On the data management of the instruments on the set of sectio cesarea, obtained several tools wear out and have to have a long lifespan. With the large number of cases of sectio cesarea in Lavalette Hospital as well as some tools that are worn out, then the function of surgical instruments will be reduced and can decline the quality of the work of the operations team in running operations of sectio cesarea. It must be anticipated by the instrumentator with the process management of a good and obedient instrument according to POS in Lavalette Hospital Malang.

In the Ministry of Health Regulation No. 004 in 2003 about policy and strategy of decentralization of health mentioned one of the strategic objectives is structuring effort in the era of health management decentralization. One of the key steps in the goal is develop a sub system maintenance and optimization of utilization of facilities and health equipment. In step of 28 of the Ministry of Health Programs mentioned above States that the success of organizing health services in a hospital or on-site service can be achieved when available operating costs and maintenance of adequate health tool and for that it shall be composed of a technical guide and POS about maintenance and optimization of utilization of the means of the hospital and health equipment (DEPKES RI, 


\section{International Journal of Science and Research (IJSR) \\ ISSN (Online): 2319-7064}

Index Copernicus Value (2015): 78.96 | Impact Factor (2015): 6.391

2003). In the management of surgical instruments, the Scrub Nurse did some stages in the management of the instrument. The role of the scrub nurse that is responsible to close or finalize the sterile field and preparing instruments for the management. This should be done by the scrub nurse to keep the management of post-operative surgical instruments can be done well, without damaging the part of instruments that will be managed after use on the operation. The stage at the start of the limit and hold, decontamination of instruments, lubrication, mounting back instruments, sterilization, packaging, and storage (J. Gundermann, 2006).

American Society for Healthcare Engineering of the Hospital Association (1996), state that the maintenance tool and a means can be done well, if planned, implemented, and controlled with appropriate maintenance activities, resulting in a tool that is safe, effective and efficient.

In every act of surgery, surgical instruments, sterilization noted to the success of the operation and prevent infection. Raizha Ananda mentioning that, one source of transmission of infection through contaminated equipment operation or not sterile. Therefore, the efforts undertaken in the management instruments must be done to reduce the risk of infection from the instruments that will be used in the operation. However, the instruments that are not free from the infection may increase the potential for nosocomial infections occurred at the time of the passing of an operation. This should pay attention to how the process of management of post-operative instruments done. Sterilization is the Act of killing and eliminating all forms of microorganisms including spores with physical or chemical procedures. One of the purposes of sterilization in health is to prevent the occurrence of cross-infection (Affdas, 2012).

At the mention above describes the interest of researchers to conduct observations on how nurses scrub nurse in compliance management of the instrument according POS on post-operative Sectio Cesaria. It is hoped this research can provide scientific documentation materials in the development of nursing perioperatif conducted especially in the management of the instrument on the post operations of Sectio Cesaria and provides basic data that can be used for further research guidelines in particular all implementation of the management instruments at the post operations of Sectio Cesaria.

\section{Method of Research}

\section{Research Design}

The design of this research is descriptive. The population was all over scrub nurses in the operating room of Lavallete Hospital Malang, in charge of the surgical instrument in managing post-operative sectio cesarea and totallly 12 people. Sample as many as 12 scrub nurses in the operating room of Lavalette Hospital Malang, in accordance with the criteria of inclusion: 1) throughout the scrub nurse who worked in the operating room of Lavalete Hospital Malang, 2) Scrub nurse operating room Lavalette Hospital hapless willing respondents. 3) Scrubs nurse who served in the management of surgical instruments on post-operative sectio cesarea. While the exclusion criteria were: 1) Scrub nurse who carried out research at the day of taking the leave, 2) Scrub nurse who conducted research on the day of admission work but did not perform surgical instrument management in the postoperative sectio cesarea in operating room of Lavalette Hospital Malang.

The variable in this study was the nurse in compliance the management of surgical instruments which consists of 7 stages. This research was conducted in the operating room of Lavelette Hospital Malang, held on 17 May-8 June 2016. The technique of data collection is the observation made by using the tools in the form of a check list that aims to obtain information about the overview of surgical instruments management processes conducted post-operative operating room. Observers give the sign check (v) on that list. Data collection activities performed are: 1) propose a research licence to the Hospital. On the recommendation of the hapless Lavalette Poltekkes Kemenkes Malang, 2) asking for permission and consent to the head of the surgical research installation in the Lavalette Hospital Malang, 3) Prepare observation sheets to be used for data retrieval, 4) Came directly to the operating room of Lavalette Hospital Malang, 5) perform the observation by following every activity management instrument of post-operation sectio caesarea, starting from the preparation of the tools, environment and preparation steps by steps in conducting the management instruments, 6) Conducting observations to entire scrub nurses who performs surgical instrument management in the postoperative sectio cesarea. Data analysis using descriptive statistics by counting at each stage of the management instruments that include the preparation of a tool, the preparation of environment as well as the steps those are carried out on the management of post-operative sectio caesarea instruments, also on the whole range of management instruments where each stage has a different maximum score. Data collected was interpreted (1) Dutifully, if all actions done properly conforms SOP, (2) less obedient, if some actions carried out according POS, or all the action yet not perfect, 3) wayward = if you ignore or do not take action appropriate based on procedure operational standard.

\section{Result}

\section{The Age of Respondents}

Table 1: Frequency distribution of the scrub nurse in the management of surgical instrument according to POS based on the age in the Lavalette Hospital Malang 2016.

\begin{tabular}{|c|c|c|c|}
\hline No & Age & $N$ & $\%$ \\
\hline 1 & $25-30$ & 2 & $16,7 \%$ \\
\hline 2 & $31-35$ & 1 & $8,3 \%$ \\
\hline 3 & $36-40$ & 5 & $41,7 \%$ \\
\hline 4 & $40-45$ & 1 & $8,3 \%$ \\
\hline 5 & $46-50$ & 3 & 25 \\
\hline 6 & $>50$ & 0 & 0 \\
\hline \multicolumn{2}{|c|}{ Total } & 12 & $100 \%$ \\
\hline
\end{tabular}

Source: Primary Data 2016

Table 1 shows above which 41.7\%) 5 (most respondents in the age range $36-40$ years. 


\section{International Journal of Science and Research (IJSR) \\ ISSN (Online): 2319-7064}

Index Copernicus Value (2015): 78.96 | Impact Factor (2015): 6.391

The Level of education of Respondents

Table 2. The frequency distribution of scrub nurse in the management of surgical instrument according to the POS based on the level of education in Lavalette Hospital Malang 2016.

\begin{tabular}{|c|l|l|l|}
\hline No & \multicolumn{1}{|c|}{ Level of Education } & N & \multicolumn{1}{c|}{$\%$} \\
\hline 1 & Nursing High School & 1 & $8,3 \%$ \\
\hline 2 & Nursing Diploma for 3 Years & 8 & $66,7 \%$ \\
\hline 3 & Bachelor Degree & 2 & $16,7 \%$ \\
\hline 4 & Diploma 4 Medical Surgical & 1 & $8,3 \%$ \\
\hline \multicolumn{2}{|c|}{ Total } & 12 & $100 \%$ \\
\hline
\end{tabular}

Source: Primary Data 2016

Table 2 shows above the level education of the respondents, Nursing Diploma for 3 Years around $8(66,7 \%)$, Bachelor Degree was $2(16,7 \%)$, Nursing High School and Diploma 4 Medical Surgical was 1 each or $8,3 \%$.

\section{The Characteristics working experiences of Respondents}

Table 3: The frequency distribution of scrub nurse in managing of medical instrumen based on POS based on the working experiences in Lavalette Hospital Malang in 2016.

\begin{tabular}{|c|c|c|c|}
\hline No & Working Experiences & $N$ & $\%$ \\
\hline 1 & $1-5$ Years & 4 & $33,2 \%$ \\
\hline 2 & $6-10$ Years & 2 & $16,7 \%$ \\
\hline 3 & $11-15$ Years & 3 & $25 \%$ \\
\hline 4 & $16-20$ Years & 2 & $16,7 \%$ \\
\hline 5 & $21-25$ Years & 1 & $8,4 \%$ \\
\hline \multicolumn{2}{|c|}{ Total } & 12 & $100 \%$ \\
\hline
\end{tabular}

Source: Primary Data 2016

Table 3 shows above the majority of working experiences of the respondents was $1-5$ years $(33,2 \%)$.

Data the Obedient of Scrub Nurses in Managing of Surgical Instrumen in each stages

First Stage Limit and Protect

Table 4The frequency distribution in managing instrumen based on the limitation and protecting in Lavalette Hospital Malang 2016.

\begin{tabular}{|c|c|c|c|c|c|}
\hline No & Category & Score & Grade \% & N & $\%$ \\
\hline 1 & Less obedient & 7 & $77 \%$ & 8 & $66,7 \%$ \\
\hline 2 & Less obedient & 8 & $88 \%$ & 4 & $33,3 \%$ \\
\hline \multicolumn{2}{|c|}{ Average } & $81 \%$ & 12 & $100 \%$ \\
\hline
\end{tabular}

Source: Primary Data 2016

Table 4 shows above the management of instrument based on limitation and protecting, average of grade of all respondents such us $81 \%$ (less obedient category).

\section{Second Stage Decontamination}

Table 5 shows the frequency distribution in managing instrumen based on decontamination stage in Lavalette Hospital Malang 2016.

\begin{tabular}{|c|c|c|c|c|c|}
\hline No & Category & Score & Grade $\%$ & $\mathrm{~N}$ & $\%$ \\
\hline 1 & Less obedient & 19 & $95 \%$ & 11 & $91,7 \%$ \\
\hline 2 & Less obedient & 17 & $85 \%$ & 1 & $8,3 \%$ \\
\hline \multicolumn{3}{|c|}{ Average } & $94 \%$ & 12 & $100 \%$ \\
\hline
\end{tabular}

Source: Primary Data 2016
Table 5 shows above the decontamination stage of the average grade all respondents are 94\% (less obedient category)

\section{Third stage Lubrication}

Table 6: The Frequency distribution of managing instrumen based on lubrication stage in Lavalette Hospital Malang 2016

\begin{tabular}{|l|l|l|l|l|l|}
\hline No & Category & Score & Grade $\%$ & N & $\%$ \\
\hline 1 & Less obedient & 5 & $50 \%$ & 11 & $91,7 \%$ \\
\hline 2 & Obedient & 10 & $100 \%$ & 1 & $8,3 \%$ \\
\hline Average & $54 \%$ & 12 & $100 \%$ \\
\hline
\end{tabular}

Source: Primary Data 2016

Tabel 6 shows above the managing instruments at the lubrication stage. The average of all respondents around 54\% (less obedient category).

\section{The 4th stage of the installation Back}

Research results at this stage of the installation back against 12 respondents who is operating room instrumentation RS. Lavalette Malang obtained that all respondents are categorized by obtaining the maximum score of wayward 8 $(100 \%)$. So the percentage of the value of the average wage in the mounting phase - a return that is $100 \%$.

\section{The 5th stage of the Packaging}

Research results at the stage of packaging against 12 respondents who is operating room instrumentation $\mathrm{RS}$. Lavalette Malang obtained that all respondents are categorized by obtaining the maximum score of wayward 10 $(100 \%)$. So the percentage of the value of the average wage in the stage of packaging was $100 \%$

\section{The 6th stage of Sterilization}

Table 7: Distribution of frequency management instrument based on stage of sterilization in RS. Lavalette Malang 2016

\begin{tabular}{|c|c|c|c|c|c|}
\hline No & Category & Score & Grade\% & N & $\%$ \\
\hline 1 & Obedient & 12 & $100 \%$ & 11 & $91,7 \%$ \\
\hline 2 & Less Obedient & 11 & $96 \%$ & 1 & $8,3 \%$ \\
\hline \multicolumn{3}{|c|}{ Average } & $99 \%$ & 12 & $100 \%$ \\
\hline
\end{tabular}

Source: Primary Data 2016

Table 7 shows the management instruments at the median value percentage, sterilization - 99\% i.e. average (category less obedient).

\section{The 7th stage Storage}

Table 8: Distribution of frequency management instrument based on stages of storage in Lavalette Hospital Malang 2016

\begin{tabular}{|l|l|l|l|l|l|}
\hline No & Category & Score & Grade\% & $N$ & $\%$ \\
\hline 1 & Less obedient & 5 & $62 \%$ & 11 & $91,7 \%$ \\
\hline 2 & Obedient & 8 & $100 \%$ & 1 & $8,3 \%$ \\
\hline \multicolumn{2}{|l|}{ Average } & $69 \%$ & 12 & $100 \%$ \\
\hline
\end{tabular}

Source: Primary Data 2016

Table 8 shows the management instruments at the percentage of the median value, storage - namely $69 \%$ average (category less obedient).

\section{Volume 6 Issue 1, January 2017




\section{International Journal of Science and Research (IJSR) \\ ISSN (Online): 2319-7064 \\ Index Copernicus Value (2015): 78.96 | Impact Factor (2015): 6.391}

\section{Discussion}

\section{Limit and hold}

In the limit and there are preparations which they did not do, i.e. use a trolley to transport all the instruments from the operating room to the management of post-operative surgical instruments. This occurs due to the perception of each respondent in bringing different instruments by using a footbath or trolley. In the Suryoputri (2011) stated that the perception of everyone especially nurses will be accepted, is meant, and remembered selectively so that compliance with the nurses in the implementation will be different.

J. Guendermann (2006) mentions that, in the management of instrument post-surgery which are limit and hold. The basic principle in dealing with contaminated instruments are limit and hold (the confined and contain). Goods that are contaminated must be at the limit in a small area and put in a closed system until ready to be processed and disposed of when used stroller system, then the instrument is dirty, trash, and cloth can be incorporated into a stroller until the train arrived on-site decontamination. From some of these things, in the limit and hold, should the respondents using the trolley for transporting instruments that will be made the management to avoid the instrument falling over.

\section{Decontamination}

The rest of the respondents can conduct the preparation tool, the preparation of the environment and the steps in the perform decontamination. But the rest of the respondents do not use boots in performing the decontamination. That is because the respondents have become accustomed to nor use the boots conducting the decontamination, although boots provided by the hospital as means self-protective to perform post-operative instrument decontamination. In performing the stages of decontamination, nurses must comply in wear PERSONAL PROTECTION (Protective Tools Themselves) including boots, because of germs, bacteria and viruses present in the instrument decontamination will be carried out. So instrumentation must wear maximum PERSONAL PROTECTION

\section{Lubrication}

This lubrication stage was getting the lowest score. This happens because, the lubrication in the Lavalette Hospital is not always carried out when the management instruments, but only the time function of the hinge of the instrument began to diminish. If the function less well, so hinge will be performed the lubrication on the hinges and spaces instruments.

It is in contrast with question J. Guendermann (2006) mentions that, after decontamination, the instrument was given a lubricant. AORN Recommended Practise (1994) States, "an instrument that part can be driven any portion thereof should be lubricated after every cleaning and appropriate written instructions from the manufacturer.". These instrument lubricants prevent rust and bacteria growth and keep the tool in order to keep functioning. Aqueous lubricant "instrument milk", is antimicrobial and watersoluble so that moisture can penetrate during sterilization. From this, then the usage of paravin (Lubrication) very in need in any management instruments to maximize the function of hinges or keep the sidelines instruments remain in good condition.

\section{Back Installation}

The rest of respondents comply in conducting installation stages back instrument, i.e. do the whole preparation tools, environment, and the preparation of the steps in conducting the installation again. J. Guendermann (2006) Stated that each instrument should be checked before the rearranged order within the set. Each instrument that need improvement should be replaced. The instrument is mounted according to standart calculation sheet of the instrument in question. In return, the nurse can check instrument function of the instruments and the completeness of the instrument.

The entire respondent in the mounting phase back instruments get interpretation value of $100 \%$. It can be supported with working period the respondents who averaged over 5 years as an operating room instrumentation of Lavalette Hospital Malang. In accordance with Ivancevich et al (2007) stated that the attitude is a mental state that is studied and organized through experience, producing a specific influence on the response of a person towards other persons, objects, situations that are related. Attitude determines the initial view of a person's response to the work and the level of compliance among individuals and organizations.

\section{Packing}

The rest of respondents comply in conducting instrument packaging stages. Packaging instruments or other medical instruments is an activity which has contributed sterilization post mainly in maintaining the safety and effectiveness of medical instruments at the time used for patient care. In the book, entitled guidelines for the installation of Central Sterilization Supply Department CSSD Central Sterile in a hospital Department of health of the Republic of Indonesia (2009), stated that the purpose and function of the packaging on the process of sterilization is to wrap the medical equipment that will be sterilized properly so that the sterility of medical equipment can be maintained until the time of the ideas. In the stage of packaging, should be noted and appropriate SOPS, to keep the sterilization tool that has been shutting down.

\section{Sterilization}

Obtained data that the 11 respondents comply in conducting sterilization according to the First POS, while respondents are less obedient. The high compliance in conducting sterilization due to the high motivation of the rest of the respondents who want to keep the sterilization tool and also reduce numbers nosocomial infections in Lavalette Hospital Malang. In accordance with Swansburg (2000) stated that, the motivation is a concept that describes the condition of a particular behaviours that stimulates, and response of the body art of human behavior. Response of sustained by energy source, called a motif that can be interpreted as a need, desire or impulse

But in conducting sterilization phase, there was one respondent who did not do the phases in sterilization, that is

\section{Volume 6 Issue 1, January 2017}




\section{International Journal of Science and Research (IJSR) \\ ISSN (Online): 2319-7064}

Index Copernicus Value (2015): 78.96 | Impact Factor (2015): 6.391

in a stage of "charging the water indicator examination until a predetermined limit". Checking of sterilization tool is indispensable, because in the process of sterilization is the stage where the tool will kill all microorganisms including spores of bacteria on objects that have been appropriately decontamination. The purpose of sterilization is to destroy all pathogenic microorganisms life forms including spores, which may already exist in the medical equipment and treatments (Sterilization Center Installation Guidelines the Central Sterile Supply Department CSSD in a hospital Department of health of the Republic of Indonesia Jakarta, 2009).

\section{Storing}

In the stages of storage, 11 respondents not using a trolley, as means of transport in carrying a pack of instruments that have been sterilized. They let cold instrument Pack first, then took him by lifting using thick gloves and put on surgical instruments tool storage cabinets that have been available. While one respondent used the trolley, as it will bring a pack of other instruments to put the instrument in the closet there has been in storage. In the move was a tool, we recommend that you use the cart to make it easier and avoids instrument garaby was brought to the place of storage.

In the manual installation of Central Sterilization Supply Department CSSD Central Sterile in a hospital Department of health of the Republic of Indonesia (2009), stated that the instruments were already in sterilisasinya so that the sanitization should be kept protected. Set of wrapped or placed in a container, stored on a shelf, open wire shelves protected from dust, humidity and damage. - Smaller objects is stored in a container labeled so that these objects are not handled in excess when someone searches for these objects.

\section{Conclusion}

Compliance with the management of instrument on postoperative sectio cesarea is as follows:

1)all respondents comply in the management of the instrument mounting the instrument back on stage (stage 4) and packaging instruments (stage 5).

2)The respondents were less strict stage management instruments with percentage average score the highest to lowest start: 6th Stage i.e. sterilization (Percentage score an average of 99\%), 2nd stage i.e. decontamination (Percentage score on average 94\%), 1st stage i.e. limit and hold (Percentage score on average $81 \%$ ), the 7 th stage i.e. instrument storage (Percentage score on average 69\%), and the 3rd stage i.e. lubrication is the lowest compliance (Percentage score an average of 54\%).

3) Overall compliance 7 stages of the management of postoperative surgical instruments sectio cesarea is less wayward Percentage score (average 85\%).

\section{References}

[1] Guendemann Barbara J, dan Fernsebner Billie. 2006. Buku Ajar Keperawatan Perioperatif. Volume 1. Jakarta: EGC
[2] Guendemann Barbara J, dan Fernsebner Billie. 2006. Buku Ajar Keperawatan Perioperatif. Volume 1. Jakarta: EGC

[3] Kelompok Kerja Persiapan Instrumen. 2005. Pemeliharaan yang Tepat pada Instrumen. $\mathrm{Ke}-8$. Saniplan.

[4] Brunner and Suddarth. 2002. Buku Ajar Keperawatan Medikal Bedah. Edisi 8. Jakarta : EGC.

[5] Setiadi. 2007. Konsep dan Penulisan Riset Keperawatan. Yogyakarta. Graha Ilmu. Wiknjosastro, H. Saifuddin, A, B. Rachimhadhi, T. 2010. Ilmu Bedah Kebidanan. Jakarta : PT Bina Pustaka Sarwono Prawirohardjo.

[6] Holifah, K. 2013. Skripsi : Gambaran Pengelolaan Set Instrumen Pasca Operasi Oleh Petugas Kamar Operasi di Instalasi Bedah Sentral RSUD Dr. Saiful Anwar.

[7] Arikunto, S. 2006. Procedure Penelitian Suatu Pendekatan Praktek. Jakarta : Rineka Cipta.

[8] Notoatmodjo, S. 2006. Metodologi Penelitian Kesehatan. Jakarta : PT Rineka Cipta. Dian Ibnu Wahid. 2008. Instrumen Bedah. Diakses di https://www.scribd.com/doc/96639393/INSTRUMENBEDAH\#download tanggal $08-11-2015$ pada pukul 18.56 WIB.

[9] Instrumen Seksio Cesarea. Diakses di http://id.shvoong.com/medicine-and-health/comparativemedicine/2228930-handling-instrumen-untuk-operasisectio/\#ixzz2g9vrBAEk tanggal 08 - 11 - 2015 pada pukul 19.30 WIB.

[10]Dekontaminasi - Pembersihan - Sterilisasi. Depkes. Diakses di http://www.scribd.com/doc/50863815/DekontaminasiPembersihan-Sterilisasi. Tanggal $12-11-2015$ pada pukul 09.45 WIB.

[11]Pedoman Instalasi Pusat Sterilisasi Central Sterile Supply Department CSSD Di Rumah Sakit Departemen Kesehatan Republik Indonesia. Diakses di http://www.scribd.com//pdf/125127495/PedomanInstalasi-Pusat-Sterilisasi-Central-Sterile-SupplyDepartmentCSSD-Di-Rumah-Sakit-DepartemenKesehatan-Republik-Indonesia-Jakarta-2009. Tanggal 12 - 11 - 2015 pada pukul 20.00 WIB.

[12]Pedoman Teknis Ruang Operasi Complete. Diakses di http://www.scribd.com//pdf/204473919/PedomanTeknis-Ruang-Operasi-Complete. Tanggal 4-12 - 2015 pada pukul 17.00 WIB.

[13] Pedoman Pengelolaan Alat Medik. Diakses di http://www.scribd.com//doc/250136037/PedomanPengelolaan-Alat-Medik. Tanggal 4 - 12 - 2015 pada pukul 18.00 WIB.

[14] Jtptunimus. Diakses di http://www.scribd.com//doc/61031/Jtptunimus-gdlanayuliani. Tanggal $6-12-2015$ pada pukul 08.00 WIB.

[15] Kepatuahan cuci tangan ok. Diakses di http://www.scribd.com//pdf/kepatuahan-cuci-tangan-ok. Tanggal 6-12-2015 pada pukul 09.00 WIB. 